\title{
DNA Damage Photoinduced by Titanium Dioxide in the Presence of Anionic Vesicles under UV Illumination: Influence of Sodium Chloride Concentration
}

\author{
Fabrice Arsac and Hisao Hidaka* \\ Frontier Research Center for the Global Environment Science, Meisei University (2-1-1 Hodokubo, Hino, Tokyo 191-8506, JAPAN)
}

\begin{abstract}
The DNA damage caused by $\mathrm{TiO}_{2}$ under in vitro conditions by $\mathrm{UV}$-A exposure in the presence of anionic vesicles of Aerosol OT (AOT) was investigated. The supercoiled form (S) in DNA plasmids was converted to the linear form $(L)$ via the relaxed form $(R)$. The DNA damage was slower in the presence of AOT vesicles prepared in aqueous $\mathrm{NaCl}$ solution. Moreover, the presence of AOT vesicles in solution after $6 \mathrm{~h}$ of UV irradiation was confirmed with an optical microscope. Probably, a fraction of the DNA was protected by random trapping during sonication. However, the addition of $\mathrm{NaCl}$ needed for the vesicle formation can decrease the $\mathrm{TiO}_{2}$ activity. On the other hand, in the absence of vesicles the $\mathrm{NaCl}$ concentration led to a profound influence on the adsorption of DNA onto the $\mathrm{TiO}_{2}$ surface. During $\mathrm{UV}$ irradiation, the degradation rate of DNA increased with increasing the salt concentration.

Solutions containing vesicles were prepared at various $\mathrm{NaCl}$ concentrations between $10 \mathrm{mM}$ and $75 \mathrm{mM}$. Consequently, the salt concentration had no significant effect on the DNA damage. The presence of $\mathrm{NaCl}$ can play a deleterious role during the photoinduced process. However, the encapsulation of a fraction of DNA is not excluded. In such conditions, the DNA could be protected against the reactive oxygen species.
\end{abstract}

Key words: DNA degradation, $\mathrm{TiO}_{2}$, AOT vesicles, gel electrophoresis

\section{INTRODUCTION}

Sunlight radiation reaching the surface of the Earth includes UV-A and UV-B. The UV-A radiation (320-400 nm) is the main component of sunlight causing tanning, actinic premature skin aging, dryness and exfoliation and dermatological photosensitivity of the skin and has been implicated in structural and cellular and skin damage ${ }^{1-4)}$. On the other hand, the UV-B radiation (290-320 nm) contributes significantly to erythema and skin cancer ${ }^{4)}$. In order to protect human skin from such damage, different kinds of sunscreen lotions have been formulated and commercialized. Typically, sunscreens contain "chemical filters", that is organic compounds that absorb strongly in the UV (most often UV-B) and "physical filters", such as $\mathrm{TiO}_{2}, \mathrm{ZnO}$ and $\mathrm{Al}_{2} \mathrm{O}_{3}$ that block UV-B and UV-A sunlight through reflection and scattering. However, these "physical filters" are able to absorb significant UV radiation ${ }^{3,5}$. Moreover, these pigments are also well-known semiconductor photocatalysts having bandgap energies of $3.2 \mathrm{eV}$ (absorption edge, $387 \mathrm{~nm}$ ) for $\mathrm{TiO}_{2}$ anatase and $\mathrm{ZnO}$, and $3.0 \mathrm{eV}(414 \mathrm{~nm})$ for $\mathrm{TiO}_{2}$ rutile. These pigments can generate harmful reactive oxygen species such as $\mathrm{O}_{2}^{-{ }^{-}}$, $\mathrm{HOO}^{\circ}$ and ${ }^{\circ} \mathrm{OH}$ radicals when subjected to UV-A/UV-B radiation ${ }^{2}$. Accordingly, these species can cause severe damage of the DNA through strand breaks, as reported in several studies ${ }^{1-6)}$. However, some anti-oxidizing agents present in the human body are able to partially protect DNA. Thus, Hidaka et $a l .{ }^{1)}$ demonstrated that the addition of $\mathrm{L}(+)$-ascorbic acid or catalase significantly reduces the DNA damage. Moreover, in a different way, the membrane of the living cell can be a protective barrier against chemical and biological assaults. In these conditions, vesicles can be employed as a simple model of a living cell, as mentioned by some authors ${ }^{7-9)}$. When one surfactant is used, the presence of salt is needed

*Correspondence to: Hisao Hidaka, Department of Chemistry, Faculty of Science and Technology, Meisei University, 2-1-1, Hodokubo, Hino, Tokyo 191-8506, JAPAN

E-mail: hidaka@epfc.meisei-u.ac.jp

Accepted August 10, 2007 (received for review July 4, 2007)

Journal of Oleo Science ISSN 1345-8957 print / ISSN 1347-3352 online

http://jos.jstage.jst.go.jp/en/ 


\section{F. Arsac and H. Hidaka}

to promote vesicle formation ${ }^{9-11)}$. Indeed, according to Grillo et $a l .{ }^{9)}$, the free ions produced by the salt dissociation can screen the repulsive electrostatic interactions between the micelles in solution and lead to vesicle formation. In a mixture containing DNA and vesicles, the entrapment of DNA within vesicles could be expected. The sonication procedure that is commonly used to prepare vesicles ${ }^{9,11-15)}$ can also provide energy to break the membrane bilayer. During this step, new vesicles are formed and the entrapment of DNA could occur. Jay and Gilbert ${ }^{14)}$ have observed the protection of DNA from digestion with DNase. They concluded that the DNA was encapsulated by random trapping during sonication.

In the present work, we investigated the DNA damage caused by $\mathrm{TiO}_{2}$ under in vitro conditions by UV-A illumination in the presence of anionic vesicles. Moreover, because vesicles cannot be formed without salt, the effect of $\mathrm{NaCl}$ concentration has been examined. The different forms of DNA plasmids (Supercoiled (S), Relaxed (R) and Linear (L)) have been assayed by agarose gel electrophoresis.

\section{EXPERIMENTAL}

\subsection{Materials}

Nanostructured $\mathrm{TiO}_{2}$ powder (P25 from Degussa) was used as photocatalyst. The $\mathrm{TiO}_{2} \mathrm{P} 25$ pigment contains $83 \%$ anatase and $17 \%$ rutile and has a specific surface of 55 $\mathrm{m}^{2} \cdot \mathrm{g}^{-1}$. The DNA plasmids (pUC18) with 2686 base-pairs $\left(\mathrm{A}_{260} / \mathrm{A}_{280}=1.76\right)$ were supplied by Nippon Gene (Wako). The DNA plasmids were used without further treatment. All solutions containing $\mathrm{NaCl}$ were prepared from an isotonic sodium chloride solution (Hikari Seiyaku, Co. Ltd.). Aerosol OT (AOT) (sodium bis-2-ethylhexylsulfosuccinate) was supplied by Wako Pure Chem. Ind., Ltd. AOT forms micelles when the concentration is above $2.48 \mathrm{mM}$ at $25^{\circ} \mathrm{C}$ as reported by Li et $a l{ }^{16)}$. In this work, the critical micellar concentration ( $\mathrm{cmc}$ ) at neutral $\mathrm{pH}$ determined by surface tension measurement is $2.3 \mathrm{mM}$ at $5^{\circ} \mathrm{C}$.

\subsection{Vesicle preparation}

An AOT solution was prepared by dissolving a weighed amount of AOT in pure water. A vessel containing $1 \mathrm{~mL}$ of the AOT solution was heated until the water evaporated. After that, the AOT film was hydrated by addition of $1 \mathrm{~mL}$ of $\mathrm{NaCl}$ solution. Then, the solution was subsequently shaken and kept for $30 \mathrm{~min}$ at $50^{\circ} \mathrm{C}$ in a water bath. During this procedure, the mixture became opalescent, indicative of the formation of AOT vesicles. By means of an optical microscope, the size and the shape of the vesicles can be observed. The solution containing AOT vesicles can be prepared at various salt concentrations. In addition, vesicles are stable after storage in a refrigerator for $12 \mathrm{~h}$ at $5^{\circ} \mathrm{C}$.

\subsection{Experimental conditions for UV exposure}

The reactor consisted of a small cylindrical glass vessel, which is placed inside a glass jar containing water and ice. The UV lamp (HPK SHL-100UVQ, 75 W) was placed above the reactor so that the UV irradiation passed through a 360 $\mathrm{nm}( \pm 11 \mathrm{~nm})$ interference filter, giving a light flux between 349 and $371 \mathrm{~nm}$ of ca. $5 \pm 0.5 \mathrm{~W} . \mathrm{m}^{-2}$. A solution containing DNA $(3 \mu \mathrm{L})$ and AOT solution, containing vesicles or micelles, $(150 \mu \mathrm{L})$ were sonicated in a bath (Branson 1200, Yamato, freq. $47 \mathrm{kHz}$ ) for $5 \mathrm{~min}$ at room temperature. Preliminary experiments were performed to confirm that no DNA damage occurs after 5 min of sonication. Then, $150 \mu \mathrm{L}$ of $\mathrm{TiO}_{2}$ solution $\left(1 \mathrm{~g} . \mathrm{L}^{-1}\right)$ was mixed with the previous solution. The final total volume of the solution was about $300 \mu \mathrm{L}$, which was cooled at $5 \pm 2^{\circ} \mathrm{C}$ under agitation with a small magnetic bar. All experiments were carried out at neutral pH.

\subsection{Gel electrophoresis assay}

Gel electrophoresis experiments were performed with a Funakoshi, model No.1316R instrument (Tokyo, Japan) equipped with an ESP 250 power supply. A Kodak Digital Science EDAS-290 analyzer system (Invistrogen Co. Ltd.) was used together with a UV trans-illuminator.

The agarose gel (2\%, agarose S, Nippon Gene Ltd.) was added to a $0.04 \mathrm{M}$ Tris-acetate, $0.001 \mathrm{M}$ EDTA buffered solution $(\mathrm{pH}=8 ; 50 \mathrm{~mL}$ ) and subsequently dissolved by microwave-assisted heating. Then, the agarose solution was poured into a UVT gel tray $(13 \times 16 \mathrm{~cm})$ to prepare a $3.5 \mathrm{~mm}$ gel thin film. The above buffer solution was added to the gel electrophoresis equipment to a depth of $10 \mathrm{~mm}$, and before solidification of the thin layer gel a comb having twenty teeth was placed to prepare a $3.5 \mathrm{~mm}$ thick gel layer after $30 \mathrm{~min}$.

After a given irradiation time, $5 \mu \mathrm{L}$ of solution was collected in a microtube and stored in the refrigerator until later analysis. Then, $1 \mu \mathrm{L}$ of loading buffer Triple Dye (Nippon Gene, Wako) was added to each illuminated sample and was gently injected into each hole of the agarose gel. Gel electrophoresis analysis was performed after an applied voltage of $100 \mathrm{~V}$ for $2 \mathrm{~h}$, then the gel was immersed in buffer solution containing ethidium bromide $\left(0.1 \mathrm{mg} \cdot \mathrm{mL}^{-1}\right)$ and finally agitated with a see-saw shaker for $30 \mathrm{~min}$. The DNA visualization of the gels was carried out using a Funakoshi NTFM-20 20 Watt UV trans-illuminator and gels pictures were recorded with a digital camera (Kodak, USA). The pattern of DNA configurations (S, R and L) was determined by using an EDAS-290 analyzer (Kodak, USA) with which, the intensity of each band could be calculated.

\section{RESULTS AND DISCUSSION}

AOT solutions were prepared at different $\mathrm{NaCl}$ concen- 
trations: 10, 25, 50 and $75 \mathrm{mM}$. Each sample were mixed with a solution containing $\mathrm{TiO}_{2}$ suspensions at a volume ratio of 1:1. Finally, the mixture contained AOT vesicles $(4.5 \mathrm{mM})$ and $\mathrm{TiO}_{2}$ suspensions $\left(0.5 \mathrm{~g} \cdot \mathrm{L}^{-1}\right)$. Two photographs of a vesicle dispersion containing $10 \mathrm{mM}$ and $75 \mathrm{mM} \mathrm{NaCl}$ are shown in Fig. 1.

Theses photographs were taken through an optical microscope and were examined at 500x magnification. As can be seen, some giant unilamellar vesicles, of about 30 $\mu \mathrm{m}$ in diameter, at both $\mathrm{NaCl}$ concentrations were formed. The arrows show the aggregation of $\mathrm{TiO}_{2}$ particles in aqueous suspensions. At first sight, the salt concentration and the $\mathrm{TiO}_{2}$ suspensions do not modify drastically the size and the stability of vesicles.

In order to better understand the impact of the vesicles, the degradation of DNA was performed in the presence of $\mathrm{AOT}$ and without $\mathrm{NaCl}$. In theses conditions, only AOT micelles were formed.

The pictures of gel electrophoresis as represented in Fig. 2 show the DNA damage in the presence of a mixture containing $\mathrm{TiO}_{2}$ suspensions and AOT. For comparison, the pattern of DNA damage in the absence of AOT is shown (Fig. 2a).

For all experiments, before irradiation, the sample was kept in the refrigerator until the end of the experiment. In all panels, before irradiation, the DNA plasmids are mainly in the supercoiled form (S). This result reveals that DNA plasmids are stable in the presence of $\mathrm{TiO}_{2}$ suspensions (Fig. 2a) but also in the presence of both AOT micelles (Fig. 2b) and AOT vesicles (Fig. 2c) in the dark. Furthermore, The L-form was not appreciably formed for the AOT-free system in the presence of $\mathrm{TiO}_{2}$ as shown in Fig. 2 (a), whereas the L-form was obviously formed and increased with UV irradiation time in the presence of AOT micelles. In both cases, the supercoiled configuration disappeared after $2 \mathrm{~h}$ of UV illumination. Meanwhile, the intensity of the relaxed band increased and then decreased according to the irradiation time. It is noteworthy that the band intensity corresponding to the linear configuration (L), detected only in Fig. 2 (a) and (b), increased slightly with exposure time as well. On the other hand, in panel (c) (Fig. 2 ), it clearly appears that the supercoiled configuration is still detected after $6 \mathrm{~h}$ of UV irradiation. Concomitantly, the intensity of the relaxed band increased slightly, whereas the linear form was not detected.

In order to show the variation of both $\mathrm{S}$ and $\mathrm{R}$ forms, the intensity of each band was determined from the panel display in Fig. 2.

The temporal changes in the relative intensity of the $\mathrm{S}$ band and the intensity of the $\mathrm{R}$ band of the gel electrophoresis patterns for damage to the DNA plasmids in the presence of different mixtures are depicted in Fig. 3.

The variation of the $\mathrm{S}$ and $\mathrm{R}$ configurations is quite simi-
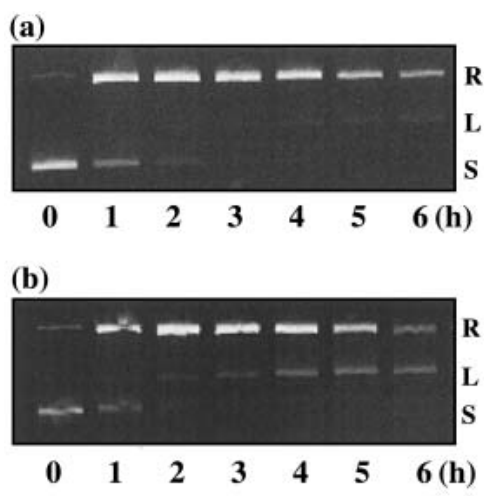

(c)

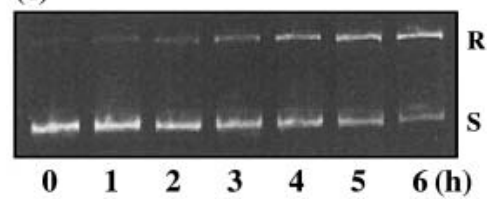

Fig. 2 Pictures of Gel Electrophoresis Measurement Showing the Photoinduced Damage of DNA Plasmids in the Presence of $\mathrm{TiO}_{2}$ : (a) without AOT, (b) in the presence of AOT micelles and (c) in the presence of AOT vesicles at $50 \mathrm{mM} \mathrm{NaCl}$.
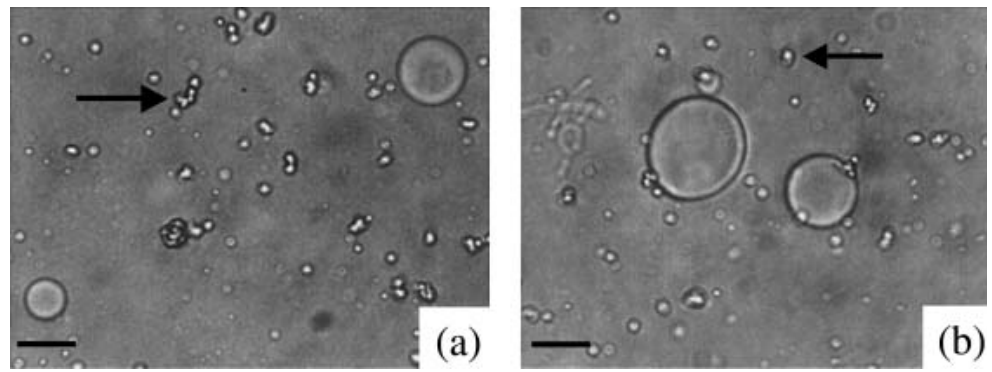

Fig. 1 Photography of AOT Vesicles $(4.5 \mathrm{mM})$ in the Presence of a Mixture Containing $\mathrm{TiO}_{2}$ Suspensions and $\mathrm{NaCl}$ Solution at 10 $\mathrm{mM}$ (a) and $75 \mathrm{mM}$ (b). The Bar Represents $20 \mu \mathrm{m}$. 


\section{F. Arsac and H. Hidaka}

lar when the DNA plasmids were irradiated both without AOT and in the presence of AOT micelles. This result indicates that AOT micelles have no significant impact with regard to the DNA damage and the $\mathrm{TiO}_{2}$ activity. Indeed, at neutral $\mathrm{pH}$, the DNA plasmids are negatively charged due to their phosphate backbone ${ }^{17}$. Therefore, owing to the electrostatic repulsion, AOT micelles cannot interact with the DNA plasmids. One the other hand, in the presence of AOT vesicles, the DNA is more stable since the supercoiled configuration is still present in solution after $6 \mathrm{~h}$ of UV illumination. At the same time, the amount of the relaxed form increases slowly during the UV exposure. In these conditions, because of electrostatic repulsion, no interactions occurred between the DNA plasmids and the anionic vesicles ${ }^{18)}$. Thus, the results as shown in Fig. 3 can be explained by considering that a fraction of DNA could be entrapped randomly within AOT vesicles. This hypothesis is consistent with the fact that vesicles were observed through the optical microscope after $6 \mathrm{~h}$ of illumination. However, the presence of $\mathrm{NaCl}$ has to be taken into account during the photoinduced process: the salt can interact with DNA and can also diminish the $\mathrm{TiO}_{2}$ activity.

The interaction between $\mathrm{NaCl}$ and DNA has been investigated. The DNA plasmids were added to a solution containing different concentration of salt $(10,25,50$ and 75

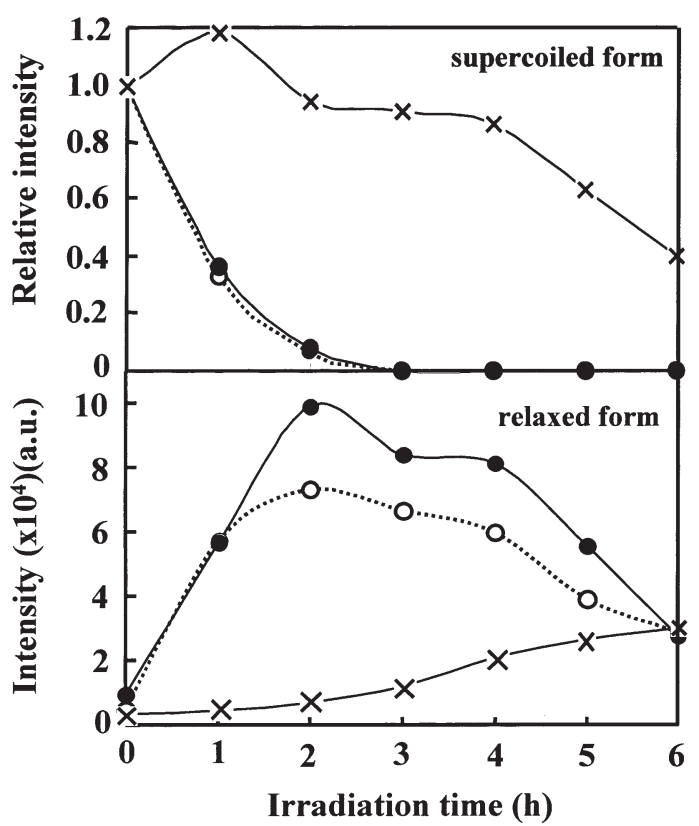

Fig. 3 Temporal Relative Intensity of Supercoiled and Relaxed Configurations subsequent to UV Irradiation of DNA Plasmids in the Presence of $\mathrm{TiO}_{2}$ : $(\bigcirc)$ without AOT, $(\bigcirc)$ in the presence of AOT micelles and $(X)$ in the presence of AOT vesicles at $50 \mathrm{mM} \mathrm{NaCl}$.
$\mathrm{mM}$ ). The results (not shown) reveal that DNA plasmids were not damaged whatever the salt concentration. Then, a similar experiment was performed by mixing the previous solution with a $\mathrm{TiO}_{2}$ suspension and then submitting it to UV exposure.

The gel electrophoresis patterns with respect to the impact of $\mathrm{NaCl}$ concentration are shown in Fig. 4.

When based on each intensity of the starting DNA plasmids before irradiation, the intensity of the $\mathrm{S}$ band decreases with increasing salt level. In addition, the amount of the relaxed form can be neglected at any salt concentration, implying that no degradation of the $\mathrm{S}$ form occurred. These results suggest that the interaction between DNA and the $\mathrm{TiO}_{2}$ surface depends on the salt concentration. Indeed, Nguyen et al. ${ }^{17)}$ have studied the adsorption of DNA supercoiled plasmids onto silica surfaces in the presence of $\mathrm{NaCl}$. They reported that negatively charged DNA is screened due to the presence of salt ${ }^{17}$. This leads to an overall decrease in the electrostatic energy barrier between the silica surface and the DNA molecules and to an increase in adsorption rate. Moreover, some studies reported that the amounts of DNA that adsorbed to sand increased with the salt concentration ${ }^{19,20)}$. In addition, it has been noticed ${ }^{19,20)}$ that van der Waals' forces can be responsible for such adsorption of DNA onto a solid. During UV illumination, the panel (Fig. 4) shows that DNA plasmids are damaged faster when the $\mathrm{NaCl}$ level is increased. The variation of the band intensity as a function of salt concentration is illustrated in Fig. $\mathbf{5}$.

For comparison, the temporal variation for both the $\mathrm{S}$ and $\mathrm{R}$ forms in the absence of $\mathrm{NaCl}$ was plotted. The degradation rate of the supercoiled form increases with the salt concentration. Furthermore, the $\mathrm{NaCl}$ promotes the degradation rate of the $\mathrm{R}$ configuration. This result is consistent with the fact that the $\mathrm{S}$ form is mainly damaged and converted into the $\mathrm{R}$ form. Nevertheless, it should be noticed that no linear form was detected (see Fig. 4), indicating that $\mathrm{L}$ form could be strongly adsorbed onto the $\mathrm{TiO}_{2}$ surface. These results are in agreement with the fact that at a high salt concentration a higher amount of DNA is adsorbed onto the $\mathrm{TiO}_{2}$ surface.

AOT vesicles are formed at any $\mathrm{NaCl}$ concentrations between $10 \mathrm{mM}$ and $75 \mathrm{mM}$. Therefore, the DNA damage in the presence of AOT vesicles at different salt level can be examined. DNA plasmid were illuminated in the presence of vesicles prepared at various $\mathrm{NaCl}$ concentrations.

All panels (illustrated in Fig. 6) were almost identical. Particularly, the analysis performed for each sample before UV irradiation shows that the amount of supercoiled form remained constant at any $\mathrm{NaCl}$ level. Owing to the presence of vesicles, the salt does not improve the DNA adsorption onto the $\mathrm{TiO}_{2}$ surface. Under UV exposure, overall the results demonstrated that a fraction of supercoiled DNA was converted into the relaxed form. Figure 7 
(a)

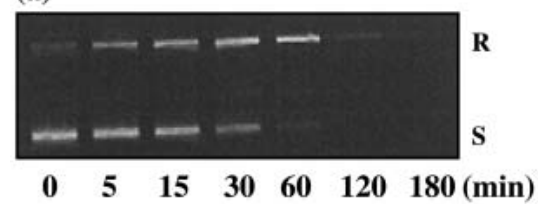

(b)

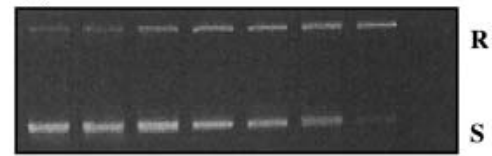

$\begin{array}{llllllll}0 & 1 & 2 & 5 & 10 & 15 & 30 & 60\end{array}(\mathrm{~min})$ (c)

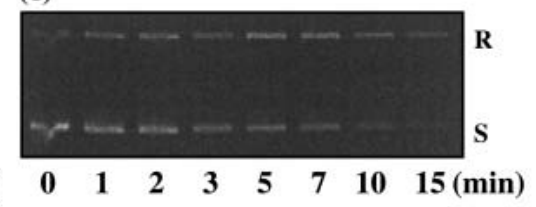

(d)

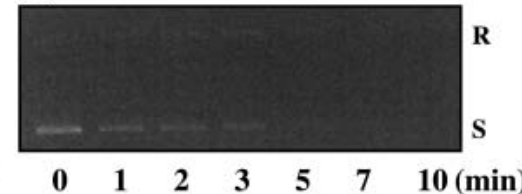

Fig. 4 Effect of $\mathrm{NaCl}$ Concentration on the Photoinduced Damage to DNA Plasmids in the Presence of $\mathrm{TiO}_{2}$ Suspensions: (a) $10 \mathrm{mM}$, (b) $25 \mathrm{mM}$, (c) $50 \mathrm{mM}$ and (d) $75 \mathrm{mM}$.

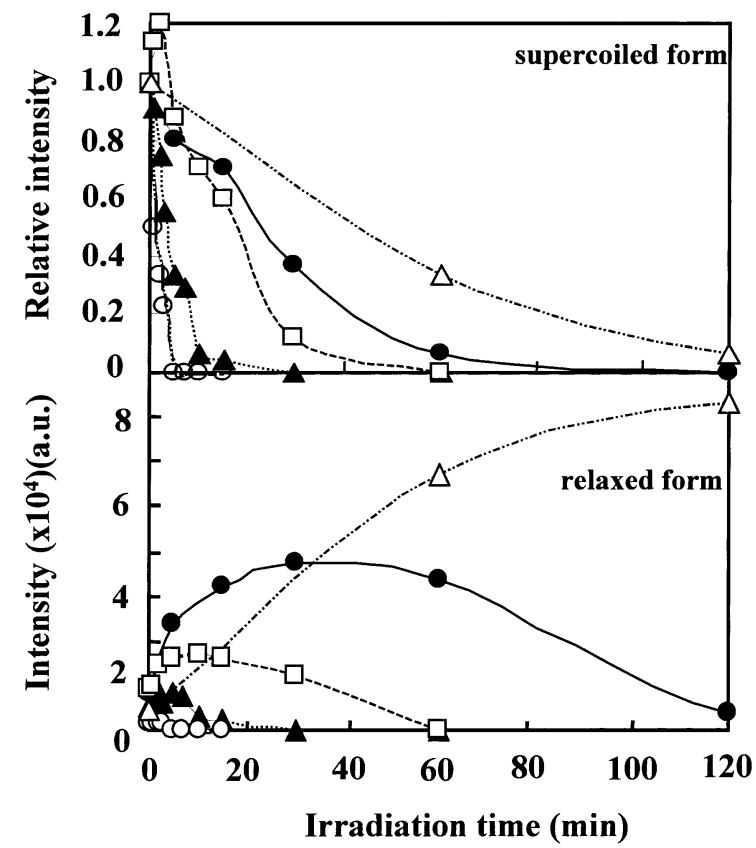

Fig. 5 Effect of $\mathrm{NaCl}$ Concentration on the Supercoiled and Relaxed Configurations in the presence of $\mathrm{TiO}_{2}$ : $(\triangle)$ without $\mathrm{NaCl},(\bigcirc) 10 \mathrm{mM},(\square) 25 \mathrm{mM}$, $50 \mathrm{mM}$ and $(\bigcirc) 75 \mathrm{mM}$.

shows the variation of both $\mathrm{S}$ and $\mathrm{R}$ bands determined from the photography of the gel electrophoresis (see Fig. 6).

For comparison, the plot of DNA damage in the presence of AOT micelles is illustrated in Fig. 7. From these results it appears that $\mathrm{NaCl}$ concentration has no significant effect on the DNA damage. Some explanations could be proposed: probably, the salt promotes the adsorption of AOT vesicles onto the $\mathrm{TiO}_{2}$ particles. Thus, the amount of DNA plasmids adsorbed decreases, which could explain why DNA remains mainly in the supercoiled form after $6 \mathrm{~h}$ of UV exposure. However, as previously mentioned, after $6 \mathrm{~h}$ of illumination, vesicles are still present in the solution. Therefore, a fraction of DNA could be encapsulated by random trapping into vesicles. In such a case, the membrane bilayer can protect the DNA plasmids against the active oxygen species generated by $\mathrm{TiO}_{2}$ under UV irradiation.

\section{CONCLUSION}

In the present work, we investigated DNA damage caused by $\mathrm{TiO}_{2}$ under in vitro conditions by UV-A irradiation in the presence of AOT vesicles. It has been demonstrated that DNA is more stable when vesicles are present in solution. Moreover, the $\mathrm{NaCl}$ concentration has no significant effect on the DNA damage. From these results, we conclude that the presence of salt could lead to a decrease of the $\mathrm{TiO}_{2}$ activity. Nevertheless, a fraction of DNA could be encapsulated within the vesicles by random trapping. In such a case, protection of the DNA against the active oxygen species generated by the $\mathrm{TiO}_{2}$ under UV illumination can be considered to be operative.

\section{ACKNOWLEDGMENT}

Financial support from the "Academic Frontier" Project for Private Universities with a matching subsidy from the Japanese Ministry of Education, Culture, Sports, Science and Technology (MEXT) for the period of 2003 - 2007, as well as from a Grant-in-Aid for Science Research (No. 17550145) is greatly acknowledged. 


\section{F. Arsac and H. Hidaka}

(a)

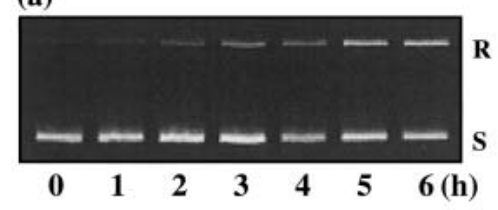

(b)

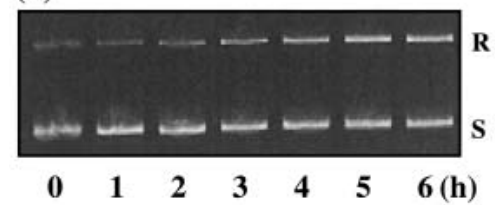

(c)

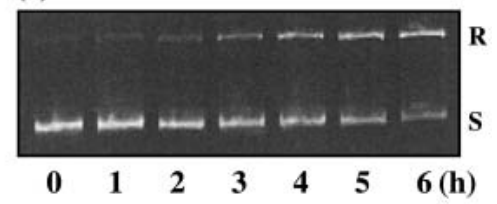

(d)

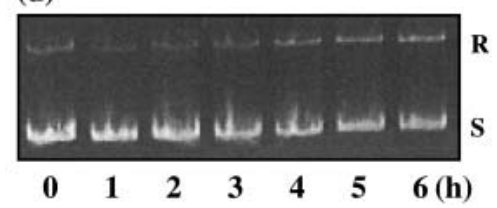

Fig. 6 Panel Display of the Nicking Results from Gel Electrophoresis Measurement Showing the Photoinduced Damage to DNA Plasmids in the Presence of $\mathrm{TiO}_{2}$ Suspensions Containing AOT Vesicles at Various $\mathrm{NaCl}$ Concentrations: (a) $10 \mathrm{mM}$, (b) $25 \mathrm{mM}$, (c) $50 \mathrm{mM}$ and (d) $75 \mathrm{mM}$.

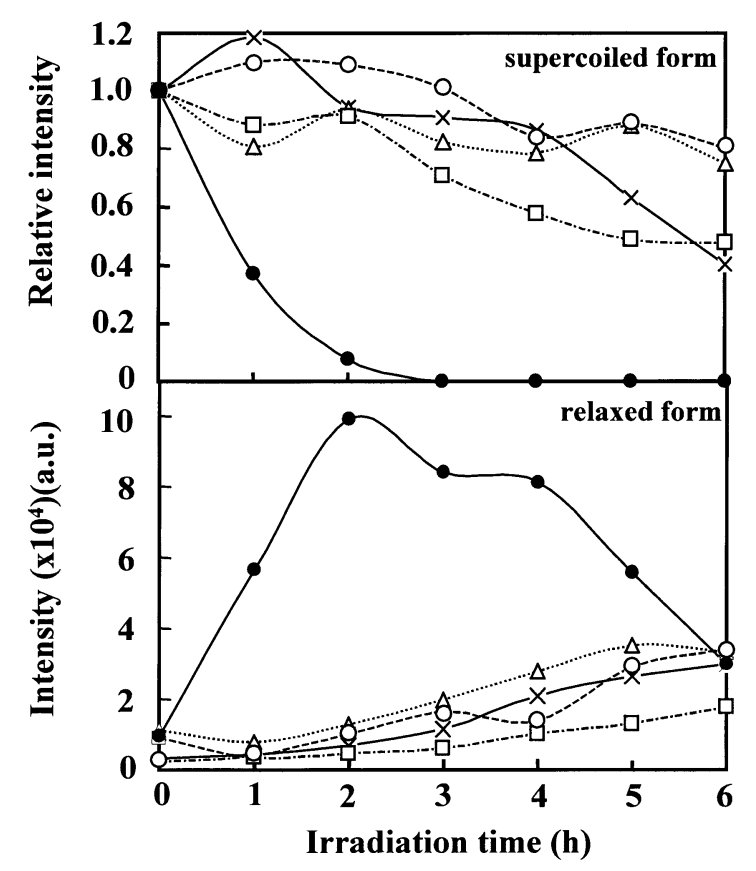

Fig. 7 Effect of $\mathrm{NaCl}$ Concentration on the Supercoiled and Relaxed Configurations in the Presence of $\mathrm{TiO}_{2}$ and AOT Vesicles: $(\bigcirc)$ without $\mathrm{NaCl},(\bigcirc) 10 \mathrm{mM}$, $(\triangle) 25 \mathrm{mM},(\times) 50 \mathrm{mM}$ and $(\square) 75 \mathrm{mM}$.

\section{References}

1. Hidaka, H.; Kobayashi, H.; Kuga, M.; Koike, T. Photoinduced characteristics of metal-oxide cosmetic pigments by agarose gel electrophoresis of DNA plasmids in vitro under UV-illumination. J. Oleo Sci. 54, 487-494 (2005).
2. Hidaka, H.; Kobayashi, H.; Koike, T.; Sato T.; Serpone, N. DNA damage photoinduced by cosmetic pigments and sunscreen agents under solar exporure and artificial UV illumination. J. Oleo Sci. 55, 249-261 (2006).

3. Serpone, N.; Salinaro, A.; Hidaka, H.; Horikoshi, S.; Knowland, J.; Dunford, R. Beneficial and deleterious effect of solar radiation. Solar Eng. 287-298 (1998).

4. Hidaka, H.; Horikoshi, S.; Serpone, N.; Knowland, J. In vitro photochemical damage to DNA, RNA and their bases by an inorganic sunscreen agent on exposure to UVA and UVB radiation. J. Photochem. Photobiol. A: Chem. 111, 205-213 (1997).

5. Dondi, D.; Albini, A.; Serpone, N. Interactions between different solar UVB/UVA filters contained in commercial suncreams and consequent loss of UV protection. Photochem. Photobiol. Sci. 5, 835-843 (2006).

6. Dunford, R.; Salinaro, A,; Cai, L.; Serpone, N.; Horikoshi, S.; Hidaka, H.; Knowland, J. Chemical oxidation and DNA damage catalysed by inorganic sunscreen ingredients. FEBS Lett. 418, 87-90 (1997).

7. Menger, F.M.; Angelova, M.I. Giant vesicles: imitating the cytological process of cell membranes. Acc. Chem. Res. 31, 789-797 (1998).

8. Menger, F.M.; Lee, S.J. Induced morphological changes in synthetic giant vesicles: growth, fusion, undulation, excretion, wounding, and healing. Langmuir 11, 36853689 (1995).

9. Grillo, I.; Kats, E.I.; Muratov, A.R. Formation and growth of anionic vesicles followed by small-angle neutron scattering. Langmuir 19, 4573-4581 (2003).

10. Renoncourt, A.; Vlachy, N.; Bauduin, P.; Drechsler, M.; Touraud, D.; Verbavatz, J.M.; Dubois, M.; Kunz, W.; Ninham, B.W. Specific alkali cation effects in the transition from micelles to vesicles through salt addition. 
Langmuir 23, 2376-2381 (2007).

11. Limin, Z.; Ganzuo, L.; Zhiwei, S. Spontaneous vesicle formation in aqueous solution of zwitterionic and anionic surfactant mixture. Colloids and Surfaces A: Physicochem. Eng. Aspects 190, 275-283 (2001).

12. Barraleiro, P.C.A.; Olofsson, G.; Alexandridis, P. Interaction of DNA with cationic vesicles: A calorimetric study. J. Phys. Chem. B. 104, 7795-7802 (2000).

13. Barraleiro, P.C.A.; Lindman, B. The kinetics of DNAcationic vesicle complex formation. J. Phys. Chem. B 107, 6208-6213 (2003).

14. Jay, D.G.; Gilbert, W. Basic protein enhances the incorporation of DNA into lipid vesicles: model for the formation of primordial cells. Proc. Natl. Acad. Sci. USA 84, 1978-1980 (1987).

15. Carmona-Ribeiro, A.M.; Yoshida, L.S.; Chaimovich, H. Salt effects on the stability of dioctadecyldimethylammonium chloride and sodium dihexadecyl phosphate vesicles. J. Phys. Chem. 89, 2928-2933 (1985).
16. Li, X.; Guo, Y.; Scriven, L.E.; Davis, H.T. Stabilization of aqueous clay suspensions with AOT vesicular solutions. Colloids and Surfaces A: Physicochem. Eng. Aspects 106, 149-159 (1996).

17. Nguyen, T.H.; Elimelech, M. Plasmid DNA adsorption on silica: kinetics and conformational changes in monovalent and divalent salts. Biomacromolecules 8 , 24-32 (2007).

18. Dias, R.; Antunes, F.; Miguel, M.; Lindman, S.; Lindman, B. DNA-lipid systems. A physical chemistry study. Brazilian J. Med. Biol. Res. 35, 509-522 (2002).

19. Lorenz, M.G.; Wackernagel, W. Adsorption of DNA to sand and variable degradation rates of adsorbed DNA. Appl. Environ. Microbiol. 53, 2948-2952 (1987).

20. Romanowski, G.; Lorentz, M.G.; Wackernagel, W. Adsorption of plasmid DNA to mineral surfaces and protection against DNase I. Appl. Environ. Microbiol. 57, 1057-1061 (1991). 